\title{
Introdução de novas raças de gado no sul do Brasil (1870-1950)
}

\author{
Introduction of new cattle breeds in southern Brazil (1870-1950) \\ Introducción de nuevas razas de ganado en el sur de Brasil (1870-1950)
}

PauloA.Zarth ${ }^{*}$

\section{Resumo}

O gado bovino (Bos taurus, Linnaeus) introduzido no Rio Grande do Sul pelos europeus no final do século XVI adaptou-se muito bem no ambiente rico em gramíneas. Ao longo do tempo, esses animais se multiplicariam e constituiriam o que se convencionou chamar de raça crioula. No final do século XIX, tomando a Argentina e o Uruguai como referência, autoridades governamentais e grandes proprietários desencadearam um processo de modernização da pecuária, substituindo o gado crioulo por raças europeias, com o objetivo de alcançar maior produtividade e inserção no mercado mundial de carnes frigorificadas. As novas raças implicaram em impactos ambientais e exigiram uma nova estrutura produtiva, baseada na fundação de instituições de pesquisa e apoio técnico, estações experimentais, associações de classe e estrutura de transportes.

Palavras-chave: Pecuária. Raças de gado. Rio Grande do Sul.

\section{Introdução}

Este texto trata do processo de introdução de novas raças de gado bovino (Bos taurus, Linnaeus) no Rio Grande do Sul, uma região historicamente marcada pelo predomínio econômico da pecuária até as primeiras décadas do século XX. A força da indústria pastoril e do grupo dominante a ela ligado propiciou a produção de uma vasta bibliografia regional, que compreende desde a apologia aos estancieiros até os estudos acadêmicos recentes, de caráter mais crítico, entre os quais se destacam as pesquisas dedicadas à escravidão nas estâncias (PETERSEN, 2008).

É visível na literatura referência recorrente a um suposto conservadorismo e tradi-

Doutor em História pela Universidade Federal Fluminense. Pesquisador. E-mail: paulo@zarth.pro.br

Recebido em 29/10/2015 - Aprovado em 12/12/2015 http://dx.doi.org/10.5335/hdtv.16n.1.6258 
cionalismo do mundo pastoril, em parte pela atuação de grupos culturais que louvam um passado idealizado das estâncias, congelado em um tempo idílico e rústico. ${ }^{1}$ De outro modo, são evidentes em diversos textos oficiais, produzidos a partir de meados do século XIX, as referências ao atraso técnico da pecuária, em que se acusam os criadores de arcaicos, rotineiros e avessos à inovação.

Porém, até certo ponto contrariando os discursos de conservadorismo, uma vanguarda de grandes proprietários pecuaristas passou a se preocupar com a modernização da produção nas últimas décadas do século XIX, desencadeando um processo de inovações que envolve novas raças de gado, cercas nos campos, manejo de pastagens, controle de doenças e desenvolvimento de centros de pesquisa. Tais ações não incluíam o questionamento da estrutura fundiária e das relações de trabalho.

Os argumentos dos modernizadores, $\mathrm{e}$ que dão sentido ao que entendem por modernização, referem-se basicamente à produtividade e às qualidades genéticas dos animais, tomando como exemplo a pecuária da Argentina e a do Uruguai, apontadas como referências para competir no crescente mercado mundial de carnes industrializadas em frigoríficos.

O ponto central da modernização gira em torno da introdução de novas raças de gado, principalmente inglesas, em substituição ao tradicional gado crioulo. A inovação teve importantes repercussões ambientais, entre elas a necessidade de manejo de pastagens e o controle de doenças e parasitas, aos quais os novos animais apresentavam fragilidade. Do ponto de vista da infraestru- tura, foi necessário um conjunto de obras e instituições, entre elas a construção do porto de Rio Grande, de postos zootécnicos e, sobretudo, frigoríficos.

Esta pesquisa tem por base a análise de conteúdo dos artigos publicados sobre o tema na Revista Agrícola do Rio Grande do Sul, na Revista Agrícola da Fronteira, na revista $A$ Estância, na revista EGATEA e nos relatórios do governo do Rio Grande do Sul, entre 1870 e 1950. Ainda que a região fosse importante na produção de cavalares, ovinos, suínos e muares, o texto está restrito ao gado bovino pela sua relevância econômica e no processo de modernização.

\section{Os bovinos crioulos no Rio Grande do Sul}

A introdução do gado vacum no Rio Grande do Sul é obra dos sacerdotes jesuítas, em data próxima ao ano 1600, e tem origem no gado desembarcado pelos portugueses em São Vicente, no século XVI, de onde alguns exemplares seguiram para o Paraguai. Naquele território e nas províncias do Rio da Prata, cruzaram com animais provenientes do Peru, de origem espanhola. O cruzamento desses animais e a seleção natural formaram um tipo de gado que se convencionou chamar de raça crioula, termo utilizado pelos pecuaristas da Argentina, do Uruguai e do sul do Brasil (PORTO, 1956).

Os jesuítas introduziram os animais vacuns e cavalares no atual território sul-rio-grandense através do Rio Uruguai, onde fundaram diversas missões com povos indígenas. O ambiente era muito favorável, com uma vegetação campestre rica em gramíneas distribuídas em dois biomas, o pam- 
pa, que cobre a metade sul e o Bioma Mata Atlântica ao norte, onde se encontram áreas de campos que formam mosaicos com as florestas do planalto (OVERBECK, 2009).

A partir das missões jesuíticas, as manadas se multiplicaram pelas pastagens abundantes "que chegavam a cobrir um homem em pé" (ABREU, 1940, p. 5). Entre 1630 e 1640, as missões foram atacadas e destruídas por caçadores de indígenas, os bandeirantes paulistas, para escravizá-los, dispersando milhares de animais, que se espalharam pelos campos, formando um imenso rebanho selvagem nas pradarias do pampa e nos campos do planalto. O retorno dos jesuítas e a organização de novas estâncias de criação deram novo impulso à criação, até serem expulsos em meados do século XVIII.

Um momento importante para a história da pecuária sulina foi a instalação das charqueadas, no final do século XVIII, baseada no trabalho escravo, para exportação de carnes conservadas pelo método de desidratação por meio do sal e exposição ao sol. Nos anos mil e oitocentos, o charque e os derivados da indústria pastoril dominaram a economia da província e geraram uma poderosa classe dominante local de grandes proprietários de terra e de trabalhadores de origem africana escravizados (RÜDIGER, 1965). O produto era comercializado, principalmente, no mercado interno, e utilizado como alimento popular e dos trabalhadores escravizados nas grandes fazendas brasileiras. Cuba era o principal mercado externo do produto.

Os saladeros da Argentina e do Uruguai eram os principais concorrentes das char- queadas sul-rio-grandenses, e a introdução de novas raças de gado de origem europeia naqueles países, em meados do século XIX, influenciou diretamente a pecuária do Rio Grande, dando origem ao processo de modernização da pecuária e da infraestrutura.

Os esforços pela modernização do rebanho sul-rio-grandense visavam ampliar a participação no mercado de carnes, que até então se limitava ao mercado interno brasileiro e à alguma participação no mercado de Cuba. Para atingir esse objetivo, era fundamental desenvolver uma rede de ferrovias e um porto adequado para colocar a produção à disposição dos centros consumidores do exterior. Era necessário também o desenvolvimento de tecnologia para garantir a qualidade e a integridade da carne, sujeita a longas viagens (o frigorífico iria resolver parte desse problema). No campo, era importante criar animais de reconhecida qualidade, segundo o novo padrão determinado pelos industriais, pelos comerciantes e pelos consumidores.

A modernização da pecuária, entretanto, não poderia ser obra apenas de produtores isolados. O processo deveria ser amplo para garantir certa homogeneidade na qualidade do rebanho e ofertar produtos dentro do padrão exigido. Para os pequenos e médios produtores, comprar os vacuns nobres era uma dificuldade econômica, e não apenas uma questão de mentalidade conservadora. Na Argentina, o alto custo da importação de raças nobres era suportado por uma vanguarda inovadora, 
[...] un número relativamente pequeño de terratenientes, no mayor de 50 hacia 1895 , capaces de hacer uso de innovaciones muy costosas en capital y de aprovechar al máximo la economía de escala (SESTO, 2004, p. 240).

Os pecuaristas menores usariam aqueles reprodutores importados e seus descendentes para mestiçagem, com um custo mais baixo.

No Rio Grande do Sul, além de uma vanguarda abastada, coube ao Estado colocar à disposição dos criadores os animais reprodutores importados. As doenças que assolavam os campos também não hesitavam em transpor as cercas das fazendas e nem mesmo os limites dos países, razão para que todos os animais fossem submetidos a um controle cada vez mais intenso no que se refere às condições sanitárias. A partir de uma pequena fazenda rudimentar, poderia vir o mal até as grandes e modernas propriedades, nas quais pastavam animais de raça nobre e mais sensíveis às doenças. $\mathrm{O}$ controle das doenças, por sua vez, implicava no desenvolvimento de pesquisas que um criador isolado não poderia realizar.

\section{Animais nobres versus crioulos}

Durante a maior parte do século XIX, e anteriores, a criação de gado no Rio Grande não recebeu melhoramentos dignos de nota. $\mathrm{O}$ gado era vendido por cabeça, e não por peso, a raça predominante e exclusiva era a crioula, e nada se fazia além de selecionar os melhores exemplares do próprio plantel, sob critérios pouco científicos. Friedrich von Weech observou, em 1827, que o gado selvagem era abatido nos campos como se fosse uma mina de ouro inesgotável até que "a necessidade e a grande diminuição dos rebanhos obrigou-os a exercer a pecuária segundo princípios racionais" (WEECH, 1991, p. 167). O professor Pinheiro Machado, da Diretoria da Produção Animal, afirma que:

[...] até meados do século passado toda a prática de criação rio-grandense era norteada por princípios rotineiros e não havia preocupações com a melhoria dos rebanhos (MACHADO, 1956, p. 33).

Ao contrário do que se afirma mais tarde, comentadores do início do século XIX escreveram que os animais eram de boa qualidade. Weech afirma: "[...] não se conhece aqui quase nenhuma doença de gado. Para este somente é perigosa a falta de água" (1991, p. 167). Em 1830, Nicolau Dreyes observou que o gado "está sempre gordo e vigoroso e as epizootias, que tanto estragos fazem na Europa, são desconhecidas, somente no inverno os animais sofrem" (1961, p. 101). Chaves, grande charqueador de Pelotas e adepto de inovações no campo, assegurava, em 1820, que os animais eram de boa qualidade:

[...] todos os gados são de boa qualidade e se excetuarmos as vizinhanças da Lagoa dos Patos e de Porto Alegre, aonde o gado é alguma coisa miúdo, em todas as mais partes nossos bois e vacas são muito corpulentos, e uma vez que lhes não faltem pastos, chegam a uma grandeza e gordura extraordinárias (1978, p. 102).

Tais comentários indicam que esses animais eram de grande rusticidade e adaptados ao ambiente após mais de dois séculos de vivência da região. Ou seja, no tocante à 
questão da raça, não havia motivo aparente para sua melhoria até meados do século XIX.

A partir dos anos 1860, a questão da raça começa a ganhar importância. Os argumentos dos pecuaristas referem-se à concorrência da Argentina e do Uruguai, cujos produtos seriam supostamente de melhor qualidade, exatamente por suas raças inglesas mais eficientes em termos de precocidade, peso e estrutura física, que haviam sido introduzidas recentemente. Com o surgimento dos frigoríficos no último quartel do século, o problema da raça tornou-se de vital importância.

\section{0 exemplo que vem do Uruguai e da Argentina}

No Uruguai, os primeiros animais de raça nobre teriam chegado em 1859, quando foram importados da Inglaterra touros e vaquilhonas com pedigree da raça Durham. Também foram importados alguns animais da raça Hereford em 1860. Em 1864, animais Hereford foram importados. Nas décadas posteriores, outras raças foram importadas, mas o Hereford tornou-se predominante naquele país, com cerca de $70 \%$ do rebanho, na década de 1950 (OLIVEIRA e SOUZA, 1956, p. 72).

Na Argentina, alguns criadores de origem inglesa iniciaram na década de 1820 a importação de touros nobres da Europa. John Miller trouxe o famoso touro Tarquin, da raça Shorthorn, "exercendo tal reprodutor notável influência durante muito tempo, sendo conhecidos seus descendentes como Tarquinos" (OLIVEIRA; SOUZA, 1956, p. 72). No entanto, até os anos 1950, tal influência seria limitada, segundo Carmen Sesto:
[...] sin duda que el mestizaje era un hecho aislado de poca significación cuantitativa y cualitativa hacia 1856, cuyo origen mítico se remontaba a un reproductor Shorrhorn: Tarquino, incorporado en 1823 ó 1826 (2004, p. 247).

A raça Shorthorn tornar-se-ia predominante na Argentina, em 1937, representava cerca de $60 \%$ dos bovinos daquele país, seguida pela Hereford e pela Aberdeen-Angus.

A influência uruguaia e argentina no Rio Grande do Sul aparece por volta de 1870, quando a introdução de raças nobres começou, mas de forma muito lenta. Em 1917, por exemplo, $82 \%$ dos animais eram crioulos, $8 \%$ Hereford, $5 \%$ Shorthorn e 5\% de raças diversas (RIO GRANDE DO SUL, 1917, p. 37). Uma referência anterior, de 1854, um tanto vaga, da câmara municipal de São Borja, informava que:

[...] o gado vaccum tem melhorado tanto em produção como em qualidade, alguns fazendeiros tem mandado vir de outras províncias diferentes raças de gado e tem produzido muito bom resultado. ${ }^{1}$

A Revista Agrícola do Rio Grande do Sul, a primeira do gênero, publicada em Pelotas, a partir de 1897, traz frequentes notícias sobre a introdução de animais Hereford, Durham, holandês, entre outras raças, incentivando a melhoria do rebanho. Em 1900, a revista anuncia que a diretoria da Sociedade Agrícola Pastoril do Rio Grande do Sul, responsável pelo periódico, encomendou animais reprodutores de raças europeias (touros e carneiros), cuja compra fora autorizada pela assembleia dos sócios. Segundo informações da revista, grande número de sócios já esta- 
va inscrito para utilizar os reprodutores (REVISTA AGRÍCOLA DO RIO GRANDE DO SUL, nov. 1900, p. 5). A mesma revista anuncia a chegada de animais Devon, reprodutores comprados em Montevidéu. Pecuaristas abastados importavam por conta própria raças nobres tanto da Argentina e do Uruguai como diretamente da Europa.

No início do século $X X$, havia certo consenso sobre a necessidade de renovar o rebanho, mas faltava acordo sobre qual a melhor raça e quais pastagens seriam as mais adequadas. Nas revistas locais dedicadas à agropecuária, travou-se um grande debate sobre o tema, em que criadores defendiam suas teses e experiências com seus animais favoritos. Além da defesa de determinada raça nobre, alguns defendiam ou combatiam a tese do cruzamento do gado importado com o gado crioulo. O professor Francisco Araújo, em um texto publicado em dezembro de 1900, analisa a questão do melhoramento dos rebanhos, referindo-se à Argentina:

Um movimento progressista se vae accentuando entre os fazendeiros riograndenses com respeito ao melhoramento de seus gados, muitos reprodutores finos tem sido importados das repúblicas visinhas para as estancias daqui, o que cabalmente demonstra que, afinal, o nosso estancieiro compenetrou-se da necessidade de cuidar com mais desvelo de suas criações. Era tempo de acompanharmos na indústria pastoril os progressos das republicas do Prata, especialmente a Argentina que se pode hoje considerar como um dos países mais adiantados na cultura pecuária (REVISTA AGRÍCOLA DO RIO GRANDE DO SUL, dez. 1900, p. 4).
O professor argumenta que as raças nobres teriam maior peso, maior rendimento de carne, além de serem mais macias e saborosas. Ele sugere a transformação dos campos em prados artificiais, seguindo o exemplo dos argentinos:

[...] lavrar completamente a campo, adubá-lo e cultivar o trigo, durante um ou dois anos para com o seu produto pagar os gastos feitos, transformando depois, com sementes forrageiras, a natureza do terreno e sua primitiva produção grosseira e pouco alimentar, poder-se-á, muito facilmente, invernar eguadas, que destruirão os pastos ruins e modificarão com o seu estrume a constituição do solo, favorecendo o aparecimento da gramma fina e nutritiva (REVISTA AGRÍCOLA DO RIO GRANDE DO SUL, dez. 1900, p. 4).

Francisco Araújo discute também com os defensores do gado crioulo, acusando-os de adeptos do espírito de rotina, e rebate a ideia de que os animais ingleses definhariam com o tempo, até chegarem a patamares inferiores aos comuns. Ao contrário, escreve que basta observar as "estâncias de fazendeiros progressistas, onde as raças Durham, Hereford prosperam admiravelmente e isto não só aqui no Rio Grande como também no Estado Oriental e na Argentina". As supostas experiências fracassadas apontadas pelos tradicionalistas seriam motivadas pela qualidade dos reprodutores:

[...] nosso fazendeiro se contenta em dar a seus rodeios, para proceder-se cobertura, animais mestiços de $1 / 2$ ou $3 / 4$ de sangue, sem indagarem em que grau taes reprodutores possuem as qualidades da raça que tem em vista adquirir (REVISTA AGRÍCOLA DO RIO GRANDE DO SUL, dez. 1900, p. 4). 
Essa observação é uma crítica comum contra a mestiçagem por cruzamento sem critérios claros. Os animais mestiços tenderiam a perder os caracteres do bovino nobre inglês. Uma seleção rigorosa poderia eleger um reprodutor mestiço de boa qualidade, mas:

[...] quem quiser andar pelo seguro, obrará com mais acerto adquirindo reprodutores puros, embora tenha que mantê-los nas condições em que foram criados, tratá-los com todo o cuidado, cercá-los de todas as atenções.

Dessa forma, a produção será "forçosamente melhor que a do gado crioulo, e o fazendeiro terá em sua venda, por preço mais elevado que o deste, a compensação de seus esforços" (REVISTA AGRÍCOLA DO RIO GRANDE DO SUL, dez. 1900, p. 4). Para tanto, o autor do artigo avisa que a Sociedade Agrícola Pastoril tem atualmente bons reprodutores, sangue puro: dois touros holandês e Hereford, para padrearem vacas pertencentes a membros da associação.

Como se pode observar no texto do professor do Liceu Rio-grandense de Agronomia e Veterinária de Pelotas, trata-se de impor o programa da escola para o melhoramento da raça bovina com o aval dos criadores reunidos na Sociedade Agrícola Pastoril. $\mathrm{O}$ alvo principal das críticas dos cientistas do liceu eram os adeptos do gado crioulo e da mestiçagem.

Apesar disso, muitos defendiam o cruzamento das raças. Em 1908, na Revista Agrícola da Fronteira, de Santana do Livramento, o criador Vicente Lucas de Lima defende e expõe as razões para o cruzamento das raças nobres com a crioula. O cruzamento contínuo, segundo Lima,
[...] se torna barato pela importação apenas do macho e tem a vantagem de, aproveitando o nosso crioulo atual, ir desenvolvendo simultaneamente as qualidades intrínsecas da raça a ser introduzida (REVISTA AGRÍCOLA DA FRONTEIRA, 1908, p. 5).

O pecuarista insiste ainda que, desse modo: "[...] substitui-se a nossa atual raça pela melhorada que o criador pretende implantar vagarosa e sistematicamente, sem o perigo de perder tempo e dinheiro" (REVISTA AGRÍCOLA DA FRONTEIRA, 1908, p. 5).

A tese do cruzamento tinha muitos adeptos, o que pode ser constatado nas defesas divulgadas em revistas e em congressos de criadores. Havia uma argumentação econômica para sustentá-la, pois os criadores preferiam cruzar os animais, aproveitando o velho plantel, a substituí-lo inteiramente pela nova raça. Certamente, esse método era largamente utilizado pelos pequenos e médios produtores, tanto sul-rio-grandenses como uruguaios e argentinos.

Na década de 1910, o debate sobre a necessidade de melhorar a raça estava em pleno andamento. Em 1913, a União dos Criadores do Rio Grande do Sul lançou o primeiro número da revista A Estância, publicada em Porto Alegre, no qual critica o tradicionalismo dos criadores e insiste que é uma imperiosa necessidade a melhoria das raças. O criador D. M. Riet, escrevendo nesse sentido, afirma:

[...] a eloquência dos fatos tem demonstrado a indiscutível conveniência de reformar por completo os costumes tradicionais, usados pelos nossos criadores primitivos, adotando práticas modernas utilizadas com notável proveito na Argentina e Uruguai. Em primeiro lugar figura o melhora- 
mento das raças na classe bovina é imperiosa necessidade substituir o gado crioulo de grandes pernas, pescoço longo (A ESTÂNCIA, mar. 1913, p. 1).

Aceita a tese da necessidade de melhoria dos rebanhos, o debate entre os criadores volta-se para a questão da melhor raça. D. M. Riet faz a defesa do Polled-Angus em diversos artigos reproduzidos na revista $A$ Estância. Em 1915, sob o título Raças bovinas: qual a mais conveniente?, ele escreve:

[...] conhecem minha decidida preferência pela raça Polled-Angus, depois de vinte anos de experiência, tendo criado simultaneamente as raças Durham e Hereford (A ESTÂNCIA, jan. 1915, p. 5).

Outros criadores defendiam o Shorthorn e o Hereford, argumentando frequentemente o sucesso das raças inglesas nas diversas exposições do continente e do exterior. $\mathrm{O}$ Aberdeen-Angus mereceu a publicação de um artigo da presidente da Sociedade Criadora Aberdeen-Angus da Grã-Bretanha, J. J. Cridwan, que expôs suas vantagens: "[...] é indubitável que constitui o melhor tipo de animal produtor de carne, membros curtos, ossos pequemos, densidade de polpa e uma qualidade muito notável" (A ESTÂNCIA, jan. 1915, p. 5). Alguns criadores preferiam realizar experiências com várias raças ao mesmo tempo, é o caso da fazenda Boa Vista de Porto Alegre, em que se criava, simultaneamente, Hereford, Shorthorn e Polled-Angus.

Além da condenação veemente do gado crioulo, outra raça que estava sendo introduzida no Brasil era condenada pelos críticos do sul; trata-se do gado zebu (Bos taurus indicus, Linnaeus), de origem indiana, e adotado pelos criadores de Minas Gerais como alternativa para modernizar o rebanho. Um debate acirrado sobre a introdução dos zebuínos no Brasil foi desencadeado entre apoiadores e críticos, envolvendo pesquisadores e pecuaristas. A análise de Joana Medrado, "mentiras e verdades da guerra contra o zebu" (2013, p. 100), na sua recente tese de doutorado, revela as diferentes posições dos conflitantes. Nas revistas do sul, esse animal era sistematicamente rejeitado e atacado pelos cientistas e criadores. Em 1913, foi publicado, na revista A Estância, um artigo do criador e especialista em pecuária Eduardo Cotrim, condenando o zebu com o argumento de que era usado pela sua resistência ao meio ambiente:

[...] apenas porque resiste as doenças do meio ambiente, porem ninguém cogita a possibilidade de se corrigir o meio, isto é, de se fazer guerra aos parasitas do gado, procurando extingui-los de modo a adaptar o campo ao desenvolvimento das raças finas oriundas do bos taurus que requerem um ambiente devidamente expurgado (A ESTÂNCIA, mar. 1913, p. 5).

Nota-se que o autor da crítica ao zebu levanta um problema de fundamental importância. Trata-se de discutir a qualidade da pastagem e dos campos no sentido mais amplo, e não apenas em relação à raça do animal, ou seja, ele sugere modificar o meio ambiente. O problema dos parasitas iria ser debatido e enfrentado pelos produtores à medida que as doenças ameaçassem abater o gado em larga escala, quando assumiam formas epidêmicas. Um artigo publicado em 1914, em A Estância, reproduz uma matéria do jornal La Tarde, do Uruguai, que condena 
o zebu naquele país, que teria adeptos apenas; segundo o autor da matéria, por dar menos trabalho (A ESTÂNCIA, ago. 1914, p. 5).

Em 1926, a revista EGATEA, da Escola de Engenharia de Porto Alegre, publicou um artigo técnico analisando o zebu, apresentando-o como inadequado em sua raça pura, mas que poderia ser utilizado para o cruzamento com o crioulo, com objetivo de passar-lhe algumas características genéticas, recomendando-o para as áreas com campos de qualidade inferior:

[...] é facto inconteste que os espécimes de puro sangue Zebu não oferecem grandes vantagens para a indústria pastoril. São animais ossudos e sua carne é fibrosa, aquosa, rígida e de mao sabor, a pele é demasiada espessa e de pouca durabilidade para objetos domésticos e sobretudo o animal tem um gênio indomável. Porém sob o ponto de vista da rusticidade e precocidade nada deixa a desejar, desafia qualquer raça bovina, mesmo os mais ormosos tipos europeus, quando colocados e explorados em meios ásperos e de pastagens de baixo valor nutritivo. Porém este produto não nos serve visto não encerrar todas as boas qualidades exigidas pelos mercados de bovinos (EGATEA, jan. 1926, p. 457).

Apesar da quase unanimidade das críticas contra o animal indiano, ele ganhou certa simpatia na região dos campos do Planalto, que seria supostamente mais atrasada em termos de inovação. O zebu é defendido pelo professor e criador Pinheiro Machado em matéria escrita para o Histórico da Diretoria da Produção Animal, de 1956, lembrando que o animal fora introduzido na região pelo seu parente, o senador José Gomes Pinheiro Machado, em 1900. Um touro da raça gir serviu de reprodutor durante muitos anos, afirmava o autor,
[...] deixando numerosos descendentes. Daí o sangue Zebu disseminou-se rapidamente por toda a região serrana, pois, ou por curiosidade ou por interesse econômi$\mathrm{co}, \mathrm{o}$ fato é que a procura de reprodutores $1 / 2$ sangue da Fazenda Biguá suplantava a oferta (OLIVEIRA; SOUZA, 1956, p. 35).

O autor acrescenta ainda, com certa ironia:

[...] posto que o Zebu fora recebido no Estado com reserva por muitos criadores da região fronteiriça, o fato é que atualmente a grande maioria dos rodeios gaúchos são pintados por sangue Zebu, desde o mais baixo grau ao puro por cruza (OLIVEIRA; SOUZA, 1956, p. 36).

\section{Boi bom, pasto bom: 0 problema das pastagens}

O problema da raça estava estreitamente ligado ao problema das pastagens. A introdução de novas raças no rebanho implicava no melhoramento das pastagens. Em uma tese defendida no $3^{\circ}$ Congresso de Criadores, em 1913, Ulisses Nonohay argumenta que os problemas do gado atribuídos à raça estão simplesmente na alimentação, e sugere à diretoria do congresso fazer uma "propaganda intensa do melhoramento dos campos como condição essencial para o melhoramento dos gados" (A ESTÂNCIA, jun. 1913, p. 5).

A questão do pasto ganha espaço em todas as revistas do início do século. Várias experiências e sugestões são propostas ao público criador. Em agosto de 1913, por exemplo, a revista A Estância publicou a experiência do posto zootécnico de São Paulo com vários tipos de forragem e também 
incluiu a opinião de criadores locais (A ESTÂNCIA, jul., 1913, p. 5).

A melhoria das pastagens implicava em custos elevados, daí a resistência de muitos produtores do início do século. A União dos Criadores, tratando disso, apresentou uma proposta no congresso de Santa Maria, em 1913, para que as associações comprassem alguns tratores e implementos para demonstração nas estâncias, e assim contribuir para o melhoramento dos campos e para a formação de forragens para a época de escassez. A proposta é baseada na seguinte constatação:

[...] até hoje ainda nenhum criador se animou a tentar a melhora dos campos pelo plantio de forragens em grandes extensões, julgando, sem dúvida, não ser de boa economia essa prática, que aliás, tem feito a riqueza dos países mais adiantados em matéria de pecuária. É natural que os criadores receiem fazer experiências não só porque não podem ser feitas em larga escala, mas principalmente porque depende da aquisição de um material caro (A ESTÂNCIA, maio 1913, p. 5).

As estações agronômicas do Rio Grande do Sul dedicaram-se desde o inicio a experiências com forrageiras, analisando o comportamento de diversas espécies quanto ao rendimento e à adaptação ao clima e ao solo. Eram, porém, experiências um tanto inconsistentes em termos econômicos, na medida em que não consideravam esses aspectos no seu sentido mais amplo, como a própria estrutura agrária das áreas pastoris. Também eram poucas as experiências com manejo de campos e com gramíneas e leguminosas nativas, adaptadas ao pastoreio. Assim, a plantação de prados artificiais de bom valor nutritivo e produtividade encontrava fortes obstáculos econômicos. Na Argentina, por exemplo, os pecuaristas encontraram uma alternativa eficiente e lucrativa para a formação de prados artificiais, arrendando parte de seus campos aos colonos imigrantes, que, no final do período de arrendamento, devolviam a terra plantada com forrageiras, como alfafa, pasto de alta qualidade nutritiva (BRIGNOLI; CARDOSO, 1983, p. 196).

Embora ocorressem experiências bem-sucedidas nas grandes fazendas, no seu conjunto, as pastagens do sul pouco tinham mudado após muitas décadas de campanha para seu melhoramento. Contudo, o número de variedade de gramíneas e leguminosas nativas é elevado (BOLDRINI, 2009), às quais se somam algumas espécies exóticas trazidas, voluntariamente ou não, por viajantes e animais que circulavam pelo continente.

Em 1948, o governo estadual decidiu investir de forma mais objetiva na questão das pastagens, criando três centros de experimentação. Duas estações agronômicas e um posto zootécnico foram dedicados ao estudo de pastagens, abrangendo três regiões distintas do estado: Uruguaiana, São Gabriel e Vacaria. As pesquisas eram encaminhadas com uma visão mais adequada à realidade. Oitocentas espécies de gramíneas e leguminosas nativas foram catalogadas e estudadas, experiências com adubação e manejo dos campos foram executadas, o plantio de forragens selecionadas também continuou sendo experimentado, mas, agora, avaliado juntamente com outros aspectos, como a utilização dos campos nativos de pastoreio e o rendimento do peso dos animais. 
Após uma série de experimentos, os doutores José Grosmann e Karl Mohrdieck, responsáveis pelas experiências, recomendavam a utilização dos campos nativos para o pastoreio, mas com a aplicação de uma série de técnicas de manejo dos campos, adubação, seleção de gramíneas nativas e limpeza para eliminar as ervas nocivas ou de pouco valor nutritivo. Para o período de inverno, quando a maioria das espécies nativas entra em período de dormência e os campos sofrem com as geadas, os técnicos recomendavam suas experiências com forrageiras artificiais como suplemento alimentar (OLIVEIRA; SOUZA, 1956, p. 115). Os pecuaristas tradicionais utilizavam como forma de manejo das pastagens a queimada no fim do inverno, com o objetivo de selecionar as plantas que, no rebrote, serviriam de alimento ao gado na primavera e no verão.

\section{Apoio estatal}

As primeiras iniciativas para melhorar o rebanho gaúcho tiveram origem privada, com apoio do governo. Muitos criadores, simplesmente influenciados pela experiência dos países do Prata, trataram de trazer animais selecionados para suas estâncias, ainda no século XIX. Ao mesmo tempo, trataram de se organizar em associações de produtores, seguindo mais uma vez o exemplo da Argentina e do Uruguai. Foram, então, publicadas as primeiras revistas científicas especializadas em pecuária e foi fundada uma escola de agronomia e veterinária, na década de 1880, com apoio do governo. Alguns criadores ficaram conhecidos pelo seu esforço no sentido de modernizar a pecuá- ria. Eram grandes proprietários e, geralmente, com alguma formação acadêmica e com participação na política do país. Um dos exemplos mais comentados é o do estancieiro, político e diplomata J. F. de Assis Brasil, proprietário da granja de Pedras Altas, que era:

[...] organizada segundo os modernos ensinamentos dos mais adiantados centros de criação, contava com exemplares importados do berço de origem das raças Devon e Jersey (OLIVEIRA; SOUZA, 1956, p. 74).

A primeira escola superior de ensino agrícola e veterinário do Rio Grande do Sul surgiu em Pelotas, em 1883, centro das charqueadas, por iniciativa de uma família de grandes pecuaristas e com a colaboração do governo municipal. A família de Eliseu Antunes Maciel, recém-falecido, mandou construir um edifício naquela cidade para abrigar uma escola pública. Na virada do século, o governo estadual, sob o comando dos positivistas, liderados por Júlio de Castilhos, e depois por Borges de Medeiros, criou a Escola de Engenharia, em 1897, que mantinha uma estação agronômica e um curso de agronomia e veterinária. A partir de 1912, a instituição preocupou-se de forma mais efetiva com a pecuária. Naquele ano, o Instituto de Agronomia e Veterinária recebeu os primeiros exemplares de uma série de reprodutores de raças nobres importados da Europa. Os reprodutores eram enviados para fazendas de todo o estado por meio do "Serviço de Monta", que levava os touros a todos os lugares (OLIVEIRA; SOUZA, 1956). Nas décadas seguintes, uma rede de estações agronômicas e postos zootécnicos seria organizada, abrangendo todo o estado. 
Os criadores, por seu lado, reivindicavam de forma recorrente a fundação de instituições oficiais de apoio à agropecuária subsidiadas pelo Estado. A União dos Criadores, nesse sentido, reivindicou a organização de postos zootécnicos, tendo em vista especialmente a aquisição de reprodutores machos para serem utilizados pelos sócios em seus próprios estabelecimentos. Em 1914, a mesma entidade solicitou ao presidente do Estado um auxílio para construir um laboratório bacteriológico veterinário para combater as doenças do gado. O presidente Borges de Medeiros, atendendo à solicitação, decidiu fornecer o material para o laboratório ao Instituto de Agronomia e Veterinária da Escola de Engenharia (A ESTÂNCIA, maio 1914, p. 5).

Um dos grandes obstáculos para a modernização dos rebanhos gaúchos era o custo financeiro do processo. Para que houvesse sucesso, era necessário que todos os criadores se dedicassem à tarefa de formação de um rebanho homogêneo em termos de qualidade e se dedicassem ao tratamento das doenças, que tinham origem nas precárias condições sanitárias dos estabelecimentos pastoris. Por isso, os criadores lutaram para conseguir o apoio do Ministério da Agricultura para auxiliar na importação de touros e para a construção de banheiros carrapaticidas, já que o carrapato é o maior transmissor de doenças. Pela Lei $n^{\circ} 2.232$, de 5 de janeiro de 1916, o Ministério da Agricultura pagava um auxílio de150\$000 rs para cada touro importado (A ESTÂNCIA, maio 1917, p. 3). Em 1915, foi construído o primeiro banheiro público federal para o gado, em Santana do Livramento, como forma de estimular e auxiliar o controle sanitário dos campos.
Outro aspecto de bastante importância para a política de inovações na pecuária foi a introdução da balança para pesar o gado. Até o princípio do século, o gado era negociado por cabeça e tudo dependia da avaliação do comprador e a concordância do estancieiro. No congresso de criadores de 1914, foi apresentada e aprovada a tese do criador Franklin Dias de Castro, redator da revista A Estância, que demonstrava a conveniência de estabelecer balanças junto aos matadouros. Essas balanças aparecem positivamente em várias notícias da referida revista.

A direção da Brazilian Extract of Meat and Factory Limited, de Cachoeira do Sul, escreveu para informar que:

[...] desde julho do presente ano temos estabelecida uma balança para receber o gado em pé e estamos resolvidos a comprar o gado na safra vindoura somente a peso (A ESTÂNCIA, dezembro 1914, p. 5).

A União dos Criadores fez uma consulta com os criadores argentinos para expor as vantagens da balança. A resposta de R. Veloso, da Sociedade Unión del Rosário, foi clara:

[...] fue uno de los partidários mas perseverantes para la imposición de las basculas para pesar el ganada, fundandose precisamente em que era ese el factor indispensable para que el verdadero desarollo de la ganaderia tuviesse o êxito que se buscaba y a la vez por que asi, se veria compensado el estimulo del que se afana por la mejora de los productos, contra el indolente que no lo hace (A ESTÂNCIA, jan. 1915, p. 5).

$\mathrm{O}$ criador argentino declarou que o gado vendido a peso era uma forma de com- 
pensar o esforço do produtor em melhorar o rebanho, apresentando animais de maior peso e precocidade. Em uma carta, o charqueador da fronteira Pedro Irigoyen reclama que ele teria sido o primeiro a instalar uma balança no Rio Grande do Sul, e afirma que "casi todos los saladeros de la frontera poseen balanzas de pesar ganado em pie" (A ESTÂNCIA, jan. 1915, p. 5). Outra novidade introduzida no início do século XX foi o registro genealógico dos animais, o Herdbook Collares (ELIAS, 2006).

\section{Novas raças, novas doenças}

Junto com as novas raças europeias vieram novas doenças. Além disso, os animais europeus eram mais sensíveis ao ambiente local, e parte deles morria ao chegar ao Rio Grande do Sul por falta de conhecimento técnico e de medicamentos adequados. Cerca de $80 \%$ dos primeiros animais importados teriam morrido por enfermidades. No Rio Grande do Sul, assim como na Argentina:

Os reprodutores importados de diversos países não só trouxeram o valor de suas qualidades raciais transmissíveis; portavam também moléstias até então desconhecidas. Não há progresso sem pesado tributo de sacrifício (OLIVEIRA; SOUZA, 1956, p. 93).

Talvez a cifra de $80 \%$ seja exagerada, mas não há dúvida de que uma série de doenças passou a causar grandes preocupações aos pecuaristas. Em todas as revistas especializadas, durante anos e anos, há um espaço assegurado para informações sobre determinadas doenças. A revista A Estância, em seu primeiro número, dedica suas primeiras páginas para o carbúnculo hemático, explicando suas características e as formas de tratamento. Outras doenças sérias eram a febre aftosa e a tristeza parasitária.

Em 1900, ocorreu uma epidemia de febre aftosa no estado; também naquele ano, chegaram as primeiras notícias de uma nova doença, conhecida na Argentina, Uruguai e Estados Unidos por a tristeza, malária bovina, ou febre do Texas. O governo argentino, logo que surgiu a doença, em 1895, criou uma comissão técnica para examiná-la, que contou com a colaboração do Dr. Ligniéres, um cientista francês enviado pelo Instituto Pasteur de Paris para tratar a doença. Em 1900, na exposição de Palermo, foi exposto o resultado das pesquisas e houve demonstrações detalhadas com as vacinas inventadas por ele (REVISTA AGRÍCOLA DO RIO GRANDE DO SUL, nov. 1900, p. 74). O micro-organismo causador da doença era transmitido pelo carrapato ao sugar o sangue dos animais. A doença era endêmica do norte da Argentina e passou a circular junto com a movimentação do gado contaminado em direção ao sul, atingindo com mais gravidade as raças europeias:

[...] nas fazendas onde esta epidemia faz seu aparecimento, os animais mestiços e finos são de preferência atacados, oferecendo as rezes crioulas certa imunidade ao mal (REVISTA AGRíCOLA DO RIO GRANDE DO SUL, set. 1900, p. 33).

Na década de 1910, os criadores sul-rio-grandenses e o governo iniciaram uma campanha para divulgar o controle sanitário dos campos. Criou-se um laboratório de bacteriologia e incentivou-se a construção 
de banheiros para combater o carrapato. As vacinas eram produzidas pelo Instituto Osvaldo Cruz, do Rio de Janeiro, que contava com uma boa equipe de cientistas e com bastante experiência. As vacinas tornaram-se comuns no início do século XX, eram anunciadas em revistas e vendidas pelas associações de criadores. Além dos medicamentos produzidos pelas instituições científicas, remédios populares eram utilizados pelos criadores. Em 1907, por exemplo, a Revista Agrícola do Rio Grande do Sul (nov. 1907, p. 133) traz uma matéria sobre a Tabacina, um extrato de tabaco usado como fungicida e indicado para tratar a sarna animal.

O problema da circulação das doenças era grave na medida em que as barreiras sanitárias eram praticamente inexistentes e ignoradas pela maioria dos criadores. Um exemplo é o caso da tuberculose bovina oriunda da Europa. Em 1901, a Sociedade Agrícola Pastoril de Pelotas apresentou queixa ao presidente da província, denunciando que animais europeus contaminados, barrados na Argentina e no Uruguai, eram vendidos pelos espertos proprietários no Rio Grande do Sul, "que não se acha aparelhado para lhes oferecer resistência" (REVISTA AGRÍCOLA DO RIO GRANDE DO SUL, abr. 1901, p. 156). Os pecuaristas pedem ao governo a contratação de um veterinário e a aquisição de equipamentos para fiscalização.

No consultório técnico da União de Criadores, os pecuaristas informavam-se sobre as formas de tratar as doenças e trocavam correspondências veiculadas na revista $A$ Estância. Pelas notícias das revistas especializadas, observa-se um intenso intercâmbio entre instituições dos Estados Unidos (Texas principalmente), França, Cuba, Argentina e Uruguai, que publicavam as suas experiências e pesquisas dedicadas ao combate de diversas doenças comuns. Assim como o projeto de melhoramento genético dos rebanhos andava lentamente, o combate às doenças andava no mesmo ritmo. Os primeiros banheiros carrapaticidas foram construídos em 1915; em 1917, existiam 177 unidades na zona da fronteira, o que era pouco, mas revelava uma tendência de crescimento.

Em 1929, o governo gaúcho interveio com maior rigor no setor e criou uma nova estrutura administrativa para cuidar da agropecuária, criando a Secretaria da Agricultura, Indústria e Comércio e uma série de órgãos específicos, entre eles as inspetorias veterinárias, organizadas em todos os municípios do Estado para fiscalizar e combater as doenças endêmicas que atacavam os animais. Era uma espécie de guarda sanitária, ainda que frágil, que tinha o objetivo de atacar os focos de doenças com recursos do Estado e, assim, garantir que os parasitas não migrassem de estância em estância, saindo dos estabelecimentos descuidados para atingir as modernas fazendas de grandes proprietários.

\section{A modernização vem do frio: os frigoríficos}

Uma das razões para o estabelecimento de um programa de melhoramento dos rebanhos deve-se ao novo patamar tecnológico do crescente mercado internacional de carne bovina. Na década de 1870, os concorrentes argentinos deram um salto de 
qualidade quando iniciaram a exportação de carne resfriada para a Europa. Foi de Buenos Aires rumo à França que partiu a primeira carga no navio frigorífico inventado pelo engenheiro francês Charles Tellier. No início da década de 1880, foram fundados os primeiros frigoríficos da Argentina e da América do Sul, inaugurando o processo de substituição dos tradicionais saladeros (PALACIO, 1956, p. 515).

Entretanto, em estudo crítico sobre a história da modernização na Argentina, Sesto afirma que a melhoria dos rebanhos foi desencadeada a partir de 1856, atendendo à demanda do mercado interno, formada por consumidores com mais poder aquisitivo, minimizando o papel dos frigoríficos nesse processo inicial. Dessa forma, a autora enfatiza as motivações econômicas internas para a mudança tecnológica:

Este programa de transformación genética fue impulsado por el mercado hogare ño entre 1856 y 1894, con una tendencia de fondo motorizada por el consumo in terno entre 1874 y 1894, al que se agrega una demanda de alto poder adquisitivo orientada hacia los reproductores mejorados, sin que se advierta la presencia activa de los frigoríficos. Esta modalidad configuró el prototipo de difusión del refinamiento vacuno: expansión de la mestización desde la zona norte hacia la central y sur de la provincia de Buenos Aires y especialización en Shorthorn, con esto remarcamos que esa elección preferencial se hizo en función del consumo hogareño (2004, p. 264).

No caso do Rio Grande do Sul, as fontes indicam que os esforços de modernização chegam um pouco mais tarde, justamente quando os frigoríficos passam a desempenhar um papel cada vez mais im- portante no mercado mundial de carnes. Ao mesmo tempo, as charqueadas passaram a comprar o gado por peso, valorizando a produtividade dos animais. É possível, ainda, que as fontes consultadas não permitam afirmar que o mercado interno sul-rio-grandense tenha também estimulado o consumo de carnes nobres.

A década de 1890 pode ser apontada como ponto de partida efetivo para a modernização dos rebanhos. Após a guerra civil de 1893-1895, com graves prejuízos para a pecuária, é que os pecuaristas trataram de se reorganizar para enfrentar a nova realidade do mercado de carnes, copiando as estratégias dos países vizinhos. O governo estadual colaborou decididamente para a conscientização dos criadores no sentido de modernizar as fazendas. Um grande debate travou-se nos primeiros anos do século, tratando sobre raças de gado, doenças, pastagens, transportes, frigoríficos e charqueadas. Revistas especializadas e associações de criadores surgiram em diversos locais. No começo dos anos 1910, um dos gargalos do Rio Grande do Sul era a falta de um porto adequado para grandes navios e a ausência de frigoríficos, essenciais para negociar com o mercado internacional. O presidente do estado, Borges de Medeiros, em 1913, escrevia que:

[...] não há dúvidas do grandioso futuro dessa indústria que para expandir-se extraordinariamente, só tem a esperar a solução final do problema dos transportes - a abertura da barra do Rio Grande à franca navegação das embarcações de longo curso. Nesse dia ao lado da exportação de charque, surgirá necessariamente a do gado em pé para abastecimento dos 
mercados nacionais e mesmo estrangeiros. E a nova indústria frigorífica virá concorrer com a das nossas velhas charqueadas. Poderá nossa pecuária disputar também o mercado mundial (1913 apud PESAVENTO, 1980, p. 75).

Em agosto de 1914, A Estância publica um artigo que esclarece que o frigorífico "é um passo largo e certo para a solução das crises pecuárias, mas ele precisa de boi bom, de raça melhorada, de muita polpa. Raça boa, campo bom" (A ESTÂNCIA, ago. 1914, p. 7). No ano seguinte, um charqueador fez a primeira tentativa de fundar um frigorífico em Santana do Livramento, mas não teve sucesso. Um esforço maior foi o da União de Criadores, quando tentou fundar o Frigorífico Rio Grande, com capitais locais. O projeto malogrou, pois não foram arrecadados fundos em quantidade suficiente. Ainda em 1915, a revista EGATEA dedica um extenso artigo sobre os frigoríficos, tratando de aspectos técnicos de seu funcionamento, enfatizando sua importância econômica para o Rio Grande do Sul e apontando para o mercado internacional de carnes:

A principal produção do nosso estado é o gado de corte, isto é, a carne. Esta só sae do estado ou sob a forma de gado em pé ou sob as de charque. Nenhuma das duas encontra mercados fáceis e esta questão tornar-se á mais séria desde que intensifiquemos a nossa produção, o que fatalmente tem de suceder para o desenvolvimento econômico de estado. $\mathrm{O}$ caminho ultimamente amplamente ventilado em nosso meio - é a exportação de carnes congeladas. Há manifesta tendência para um aumento de procura do gênero, abrindo-se novos mercados, ao mesmo tempo que as fontes de suprimento tendem a decrescer. À América do Sul provavelmente caberá em não longe futuro abastecer uma grande parte de taes mercados e enquanto os nossos vizinhos do Prata fazem já entrada nesses campos de comércio, nós estamos ainda de todo desaparelhado (EGATEA, jan. 1915, p. 170).

Apesar dos esforços no estado, o primeiro frigorífico brasileiro foi instalado no estado de São Paulo, em 1913, gerando grande frustração entre os criadores sul-rio-grandenses. O jornal O Diário, de Porto Alegre, atribuiu ao "espírito de rotina dos nossos criadores o fato de haver o Estado de São Paulo tomado a primeira iniciativa na exportação de carnes frigorificadas" (A ESTÂNCIA, fev. 1915, p. 441). A União dos Criadores rebateu a crítica do jornal, argumentando que o gado daquele estado era de qualidade pior que o gaúcho e que a razão de tudo era a falta de um porto que possibilitasse a exportação (A ESTÂNCIA, fev. 1915, p. 441).

Em 1917, finalmente, o Rio Grande do Sul viu o frigorífico virar realidade. O primeiro foi o de uma empresa de Chicago, a Swift, com atuação na Argentina, que construiu sua fábrica na cidade de Rio Grande, quando o porto já estava devidamente melhorado para permitir o acesso de navios de grande calado. Naquele mesmo ano, foram construídos os frigoríficos da Wilson Company e da Armour Company, ambos em Santana do Livramento, na fronteira com o Uruguai. Essa cidade conectava-se à rede ferroviária uruguaia, inaugurada nos anos 1890, o que possibilitava a exportação pelo porto de Montevidéu.

Como era esperado, a instalação dos frigoríficos e o melhoramento dos rebanhos 
produziram efeitos positivos. O presidente do Estado, em sua mensagem de 1919, dizia:

[...] não há propaganda mais persuasiva nem ação mais prática e eficaz para estimular e acelerar o refinamento do gado de corte do que aquelas que exercem os próprios frigoríficos com severa seleção na qualidade e peso dos animais entrados em seus matadouros e pelos quais, por compensação, não regateiam os preços mais altos e mais remuneradores. Em geral, o tipo de novilho para o frigorífico é o da raça Durham, Hereford e Polled-Angus. Hoje que a indústria do frio já se instalou entre nós, com tendência a radicar-se e desenvolver se soberbamente, o que nos cumpre e urge fazer é imitar o maravilhoso exemplo da Argentina e dotar a nossa pecuária de todos os aperfeiçoamentos de que é suscetível (BORGES DE MEDEIROS, 1919 apud PESAVENTO, 1980, p. 142).

A ação dos criadores sul-rio-grandenses pelo melhoramento dos rebanhos seria recompensada pelo mercado mundial, para o qual se empenhavam. Segundo Sandra Pesavento, o Rio Grande do Sul exportava 13,6\% das carnes congeladas brasileiras em 1919, primeiro ano de sua participação no setor, mas atingiu 52,5\% em 1921. Os produtos dos frigoríficos de São Paulo e Rio de Janeiro "estavam sendo recusados na França, Inglaterra, Estados Unidos e Itália, com aceitação só pelos exércitos em batalha" (PESAVENTO, 1980, p. 147).

Apesar da expectativa de ser o frigorífico o futuro inexorável da indústria de carnes, o charque manteve-se ainda por longo tempo no mercado. Na década de 1920, ocorreu uma crise no setor em decorrência da Primeira Guerra Mundial, o que estimulou a produção das charqueadas, tanto no Rio Grande do Sul como na Argentina e no Uruguai:
[...] quer o Uruguay como a própria Argentina se viram forçados a retomar as suas velhas actividades saladeris, restringindo das matanças para os frigoríficos e reactivando-as para o charque (VARGAS, 1930, p. 19).

\section{Conclusões}

A substituição do rebanho crioulo no Rio Grande do Sul por novas raças de origem europeia foi um processo lento, mas contínuo, comandado por uma vanguarda de pecuaristas abastados com incentivos do Estado. Depois de mais de dois séculos convivendo nos campos sulinos, o gado crioulo adaptou-se sem grandes problemas ao meio ambiente local e atendeu às demandas dos criadores e da indústria de charque até meados do século XIX. Elogiados por cronistas no início dos anos 1800, pela sua resistência e qualidade, foram gradativamente considerados inferiores diante das novas raças que chegavam aos campos do Uruguai e da Argentina.

A ideia de introduzir novas raças europeias aparece nos documentos analisados sempre com referências à pecuária dos países do Prata, concorrentes diretos dos pecuaristas sul-rio-grandenses no mercado de carnes. Os textos partem do princípio da falta de manejo genético dos animais crioulos e da mentalidade conservadora dos criadores, em termos tecnológicos. Ao mesmo tempo, são explícitos em relação ao alto custo da importação de touros e matrizes europeias assim como aos problemas de adaptação dos animais ao meio ambiente.

Os argumentos dos inovadores em favor das novas raças referem-se ao maior 
rendimento em peso e à qualidade da carne. As evidências e os preços diferenciados parecem confirmar a preferência dos consumidores pelos animais nobres. Porém, o problema fundamental era o custo da mudança em uma atividade com baixo investimento de capital. O suposto arcaísmo dos criadores pode ser entendido como cautela necessária diante das incertezas e dos problemas inerentes às novas raças. Uma solução foi a prática de cruzamentos das raças, com custos e riscos mais baixos, amplamente adotada por pecuaristas sul-rio-grandenses e também dos países vizinhos.

Coube aos estancieiros mais abastados a formação de rebanhos puros, cada qual defendendo a qualidade desta ou daquela raça. Entretanto, os riscos ambientais para as novas raças exigiam mudanças em todas as estâncias, como forma de controlar parasitas e doenças contagiosas que afetavam com mais gravidade aqueles animais. De certa forma, tratava-se de extinguir os próprios criadores ditos atrasados, geralmente pequenos e médios proprietários que preferiam a segurança dos rústicos crioulos. Coube às instituições do Estado, por meio de controles e exigências sanitárias assim como de apoio técnico, induzir as mudanças.

Na década de 1950, a julgar pela observação de Pinheiro Machado, no relatório da Diretoria de Produção Animal, o ciclo do gado crioulo teria terminado, absorvido pelo cruzamento com as raças britânicas: “[...] não mais existe nos rodeios gaúchos o tipo de antigo gado regional" (1956, p. 33).

\section{Abstract}

The cattle (Bos taurus, Linnaeus) introduced in Rio Grande do Sul by Europeans in the late sixteenth century has adapted very well in the environment rich in grasses. Over time these animals would multiply and constitute the so-called Crioula race. In the late nineteenth century, taking Argentina and Uruguay as reference, government officials and large landowners triggered a livestock modernization process, replacing the Crioulo cattle by European breeds in order to achieve higher productivity and integration into the world market through refrigerated meats. The new races resulted in environmental impacts and required a new production structure, based on the foundation of research institutions and technical support; experimental stations; trade associations and transport infrastructure.

Keywords: Livestock. Cattle breeds. Rio Grande do Sul.

\section{Resumen}

Los bovinos (Bos taurus, Linnaeus) introducidos en Río Grande do Sul por los europeos a finales del siglo XVI se ha adaptado muy bien en el ambiente rico en pastos. Con el tiempo estos animales se multiplicarían y constituyen la llamada raza criolla. A finales del siglo XIX, teniendo Argentina y Uruguay como referencia, los funcionarios del gobierno y los grandes propietarios de tierras provocaron un proceso de modernización ganadera, en sustitución de los bovinos criollos por las razas europeas con el fin de lograr 
una mayor productividad y la integración en el mercado mundial de carnes refrigeradas. Las nuevas raças resultaron en impactos ambientales y requieren una nueva estructura de producción, basado en la fundación de instituciones de investigación y apoyo técnico; estaciones experimentales; asociaciones de productores y la infraestructura de transporte.

Palabras clave: Ganadería. Razas de ganado. Río Grande del Sur.

\section{Nota}

1 Correspondência da Câmara Municipal de São Borja. 31 ago. 1854. Arquivo Histórico do RS.

\section{Referências}

A ESTÂNCIA. Porto Alegre: Orgam da União dos Criadores do Rio Grande do Sul, 19131917.

ABREU, Florêncio de. O gado bovino e sua influência sobre a antropogeografia do Rio Grande do Sul. In: CONGRESSO SUL-RIOGRANDENSE DEGEOGRAFIA, 3, 1940, Porto Alegre. Anais... Porto Alegre: Livraria do GLOBO, 1940. v. 4. p. 5-26.

BOLDRINI, Ilsi Lob. A flora dos campos do Rio Grande do Sul. In: PILLAR, Valério De Patta et al. Campos sulinos: conservação e uso sustentável da biodiversidade. Brasília: MMA, 2009. p. 63-77.

BRIGNOLI, Hector P.; CARDOSO, Ciro F. S. História econômica da América Latina. Rio de Janeiro: Graal, 1983.

CHAVES, Antônio José Gonçalves. Memórias ecônomo-políticas sobre a administração pública do Brasil. Porto Alegre: Cia. União de Seguros Gerais, 1978. (Coleção Erus). (Edição fac-símile da Typographia Nacional, Rio de Janeiro: 1823).
COARACY, V. Frigoríficos. EGATEA, Revista da Escola de Engenharia de Porto Alegre, Porto Alegre, v. 1, n. 4, p. 170, jan. 1915.

DREYES, Nicolau. Notícia descritiva da Província do Rio Grande de São Pedro. Porto Alegre: Globo; INL, 1961.

ELIAS, Amilton Cardoso. O centenário do Herd-Book Collares: 100 anos. Pelotas: Futura, 2006.

LIMA, Vicente Lucas de. Melhoramentos das raças. Revista Agrícola da Fronteira, Santana do Livramento, a. I, n. 2, p. 5, 1908.

MACHADO, Dulphe Pinheiro. O Zebú e o melhoramento do gado crioulo. EGATEA, Revista da Escola de Engenharia de Porto Alegre, Porto Alegre, v. 6, p. 457, jan./fev. 1926.

Origem e evolução da pecuária rio-grandense. In: OLIVEIRA,Waldemar Peixoto de; SOUZA, João Sérgio de. Histórico da Diretoria da Produção Animal, Porto Alegre: Secretaria da Agricultura, 1956. p. 33.

MEDRADO, Joana. Do pastoreio à pecuária: a invenção da modernização rural nos sertões do Brasil Central. Tese (Doutorado em História) - Instituto de Ciências Humanas e Filosofia, Universidade Federal Fluminense, 2013.

OLIVEIRA, Waldemar P.; SOUZA, João S. (Org.) Histórico da Diretoria da Produção Animal. Porto Alegre: Secretaria da Agricultura, 1956.

OVERBECK, Gerhard Ernst et al. Os campos sulinos: um bioma negligenciado. In: PILLAR, Valério De Patta et al. Campos sulinos: conservação e uso sustentável da biodiversidade. Brasília: MMA, 2009. p. 26-40.

PALACIO, Ernesto. Historia de la Argentina. Buenos Aires: ALPE, 1956.

PESAVENTO, Sandra Jatahy. República Velha gaúcha. Porto Alegre: Movimento, 1980.

PETERSEN, Sílvia Regina Ferraz. História da escravidão e da liberdade no Brasil Meridional. Revista Brasileira de História, São Paulo, v. 28, n. 56, p. 575-578, 2008. Disponível em: <http:// www.scielo.br/scielo.php?script $=$ sci_ 
arttext\&pid=S0102-01882008000200015\&lng=e n\&nrm=iso>. Acesso em: 28 out. 2015.

PORTO, Aurélio. Antecedentes econômicos políticos da fundação dos povos. Boletim Geográfico, Porto Alegre, n. 135, nov./dez. 1956.

REVISTA AGRÍCOLA DO RIO GRANDE DO SUL. Pelotas: Sociedade Agrícola Pastoril do Rio Grande do Sul, 1900-1907.

RIO GRANDE DO SUL. Repartição de Estatística do RS. Trabalho apresentado na Exposição Nacional de Pecuária do Rio de Janeiro. Porto Alegre: Globo, 1917.

RÜDIGER, Sebalt. Colonização e propriedades $d a$ terra no Rio Grande do Sul Séc. XVIII. Porto Alegre: IEL, 1965.

SESTO, Carmen. El cambio racial del vacuno: ¿Un fenómeno de la demanda interna [18561894]?. Anuario del Instituto de Historia Argentina, Buenos Aires, n. 4. p. 264, 2004. Disponível em: <http://www.fuentesmemoria.fahce. unlp.edu.ar/art_revistas/pr.3256/pr.3256. pdf $>$. Acesso em: 28 out. 2015.

VARGAS, Getúlio. Mensagem enviada à Assembleia dos representantes do Estado do Rio Grande do Sul pelo presidente Getulio Vargas. Porto Alegre: A Federação, 1930.

WEECH, Friedrich von. (1827). A agricultura e o comércio do Brasil no sistema colonial. São Paulo: Martins Fontes, 1991. 